\title{
Squared nasal root, nasal voice -indicators of 22 q11.2 deletion in patients with psychiatric illness
}

\author{
Jyothilakshmi Annavarapu*, Prabhavathi Halappa, Niby J Elackatt, Mitesh Shetty, Sridevi Hegde \\ From International Conference on Human Genetics and 39th Annual Meeting of the Indian Society of \\ Human Genetics (ISHG) \\ Ahmadabad, India. 23-25 January 2013
}

\section{Background}

22q11.2 Deletion Syndrome DGS (22q11) is a micro deletion syndrome caused by the deletion on chromosome 22 . It is a multi system disorder which affects Cardiovascular system, immune system, facial features covered by acronym CATCH22 (Cardiac defects aortic arch anomalies, conotruncal anomalies, ventricular septal defect, patent ductus arteriosis and tetra logy of fallot; Abnormal facies ; Thymic hypoplasia; Hypocalcemia). Few children will not present with all of the above clinical features but only delayed motor mile stones, learning disability and mild behavioral issues which may progress onto psychiatric illness in adulthood. In this study, we aim to study the prevalence of DGS in patients with psychiatric illness.

\section{Materials and methods}

To further explore physical, behavioral and psychiatric findings associated with $22 \mathrm{q} 11$ deletion in adults with psychiatric illness, we assessed 12 patients. All were confirmed psychiatric cases referred from a well-known Institute for mental health studies and also had mild facial dysmorphism. All patients were screened using the clinical checklist for DGS and Fluorescence In Situ Hybridization(FISH) studies was conducted using the probe specific for TUPLE1 gene located on chromosome 22 q11.2 in cultured blood samples.

\section{Results}

Out of 12 cases, six cases (50\%) tested positive for 22q11 deletion indicating a strong association between 22q11.2 deletion syndrome and psychiatric illness in adult population. All six patients presented with squared nasal root, and nasal voice in addition to psychosis and one also had cardiac abnormality (VSD). Recent studies

\footnotetext{
* Correspondence: genetics@manipalhospitals.com
}

Dept. of Medical Genetics, Manipal Hospital, Bangalore, India report that Digeorge critical region (DGCR) spanning up to $2 \mathrm{Mb}$ on chromosome 22q11 region contains several genes like TBX1, GNB1L, PRODH and ZDHHC8 which are strong candidate genes for schizophrenia susceptibility. In conclusion, all patients with psychiatric illness, squared nasal root and nasal voice should be investigated for DGS.

Published: 21 January 2014

doi:10.1186/1755-8166-7-S1-P76

Cite this article as: Annavarapu et al:: Squared nasal root, nasal voice -indicators of 22 q11.2 deletion in patients with psychiatric illness. Molecular Cytogenetics 2014 7(Suppl 1):P76.
Submit your next manuscript to BioMed Central and take full advantage of:

- Convenient online submission

- Thorough peer review

- No space constraints or color figure charges

- Immediate publication on acceptance

- Inclusion in PubMed, CAS, Scopus and Google Scholar

- Research which is freely available for redistribution
() Biomed Central 